\title{
Covid-19 Vocabulary in English Arabic and Indonesian Multimedia as Social Practices
}

\author{
Darsita Suparno $^{1 *}$, Santje Inneke Iroth ${ }^{2}$, Donald Matheos Rattu ${ }^{3}$, Nuryani $^{4}$ \\ ${ }^{1}$ Translation Department, FAH Universitas Islam Negeri Syarif Hidayatullah, Jakarta 15412, Indonesia \\ ${ }^{2}$ Indonesian Department, FBS Universitas Negeri Manado, Manado, Sulawesi Utara 95618, Indonesia \\ ${ }^{3}$ Indonesian Department, FBS Universitas Negeri Manado, Manado, Sulawesi Utara 95618, Indonesia \\ ${ }^{4}$ Indonesian Department, FITK Universitas Islam Negeri Syarif Hidayatullah, Jakarta 15412, Indonesia \\ *Corresponding author. Email: darsitasuparno@uinjkt.ac.id
}

\begin{abstract}
This paper studies language and creativity on the covid-19 term, social environment and social practices and multimedia that occurs in English, Arabic and Indonesian. The study attempts to find answers to the following questions: a) how are the vocabulary forms related to covid-19 used in English, Arabic, and Indonesian in providing information about the disease?, b) what is the lexical structure of synonym, borrowing, abbreviation, acronym in English, Arabic, and Indonesian? This study aims to describe the emergence of new English, Arabic, Indonesian vocabularies related to COVID-19 by using Carter's theory. It used multimedia or news-paper, text, graphics, animation, audio and video information from BBC, CNN online other social media resources that show covid-19 vocabularies as the key standard procedure for collecting data. The criteria used to analyze the data were orthographic, sound-change, phonological, morpheme contrast, creativity, language and social context. This research used descriptive qualitative method. The source of the data was basic-word vocabulary. The data are collected using three dictionaries as sources to get information and were analyzed using structural linguistics, especially phonology, morphology, and semantics. The result shows several aspects of findings such as identifying synonym, borrowing, abbreviation, and acronym. Using the multimedia from BBC, $\mathrm{CNN}$ online, the result of this study shows that there are 150 vocabularies. Using the linguistic elements, the vocabularies that describe covid-19 concept are classified into 102 words and 48 phrases.
\end{abstract}

\section{Keywords: language, multimedia, social environment, social practice}

\section{INTRODUCTION}

On December 31 2019, the Chinese government reported the presence of new corona virus disease known as Covid-19 for the first time[1]-[4].Wuhan is known to be the first region isolated by the Chinese government in order to prevent the spread of the disease. The disease which main symptoms are loss of taste or smell, diarrhea and headache soon became an outbreak that has been reported by the World Health Organization (WHO) as an international health phenomenon that needs a serious attention to prevent its widespread transmission [5]. By the end of February, the disease had spread to 24 countries outside China with new cases emerging. Many countries did many things to anticipate and slow down the transmission of the disease. The government of the respective country worked with WHO to monitor the situation and prevent further spread of the disease. They shared information on the disease and advised the public on how to keep healthy. On March 11, 2020 the public became aware from WHO that the term pandemic refers to the spread of infectious disease across a large region. Not only does it affect health but it also disrupts many other aspects of life, such as social interactions, daily activities, education, worship, economic, population movement, and language use. Every government takes large-scale actions, gives instruction, and provides information to the public to make changes in social practices in society, such as wearing masks, washing hands, social distance to combat the rapid spread of disease. Based on that fact, effective communication from the government to their societies plays a crucial role in dealing with outbreaks and ways of preventing transmission.

Recently, researchers have shown an increased interest in pandemic communication that is connected with multimedia. Communication carried out by the government to the public is identified as mass communication. At present, technological developments have formed social media as a means of delivering 
news. Social media is a means of communication that has the primary function of conveying messages from the government to the public. It needs to inform and advise matters regarding disease prevention, such as sanitation and hygiene, maintaining social distancing, hand washing, wearing masks, etc. In a pandemic situation, social media plays a role because it allows people to share news, personal experiences from their point of view, in real-time, at any given time and in a rapid manner. Covid-19 related vocabulary is increasingly recognized as a serious, worldwide public health concern. Research on the use of multimedia to understand vocabulary to new epidemic has been conducted, such as the effect of jargon in covid-19 crisis communication [6]-[8] the vocabulary used in news on a disease such as Covid-19 in English, Spanish, and French [9].

Multimedia, together with health organizations and the government, give out information to the public about the prevention of Covid-19. Theoretically, language and creativity are psychological phenomena that have been observed by its representation. Social practice or social activities are represented by creativity in spoken language. The oral language can be expressed by the ideas. The person makes an effort to communicate his thoughts, both thoughts that have based on the results of thinking convergent or divergent. Some research has been done in this direction [6], [8], [10], [11]. In our opinion, the application of multimedia to language creativity has the following two problems, a) how the vocabulary forms related to covid-19 used by English, Arabic, and Indonesian in providing information about the disease? b) what is the lexical structure of synonym, borrowing, abbreviation, acronym in English, Arabic, and Indonesian?

According to the basis of multimedia sources type of public communication, we divided the existed work into two categories. In the context of communication science, experimental studies reveal that the existence of jargon serves as a signal that information has easily understood by the public [8], [11], [12] gives out Event-based surveillance (EBS) systems information source to invent early signals of disease appearance, online news covid-19 vocabularies. It solves the ProMED was conducted to evaluate disease presence as follows: (1) the capacity of three eventbased surveillance (EBS) systems (ProMed, HealthMap and PADI-web) to reveal first Covid-19 appearance signals, (2) ProMed could detect specific vocabularies that was related to 'pneumonia symptoms,' The results of this study indicate that the three EBS systems complement each other regarding data sources. The EBS method can be used by the scholar to find out various vocabularies related to disease outbreaks to increase the detection of future unknown disease outbreaks. Shih et.al [13] reported that framing and cycle as a theoretical framework, this study shows that the print media transmits a lot of news about epidemics, public health, such as mad cow disease, West Nile virus, and bird flu. This study has found that "actions of the government" and "consequences" are the two frames that journalists use consistently built a story about the epidemic in the New York Times newspaper. Shi analysed three health problems, namely, (bird flu, mad cow disease, and West Nile virus). These diseases have analysed based on the aspect of the dangers of the epidemic that occurred in the United States and has the potential to spread beyond it. This study shows that journalists tend to focus on events (i.e., specific examples of hazardous situations and their consequences. Much of the media coverage informing these three issues tends to follow a comparable trend.

In covering the three diseases, journalists can highlight the aspects of the number of victims, the number of cases worldwide, and the possible consequences of the level of self-protection concern for public. This study is supported by [14]-[17] who write the content information of covid-19, several features, interactive feature to facilitate the multimedia communication, [18]-[21] Understanding the new concept related to covid-19 and commenting, analysis of news in government posts have identified by public awareness. In that way, multimedia users can get new vocabulary in health problems [19]. Anisya [22], [3], [4] explained that the government directs people to obey social practices.

\section{METHODOLOGY}

This study applies qualitative approach with content analysis the issue of vocabularies represented in multimedia, such as website, WhatsApp, Line, newspaper. Qualitative analyzes the vocabularies by selecting data from covid-19 related events, news, issue and the writers makes an interpretation of what is happening based on the experience as the observation. This study refers to deep understanding of the form and the meaning of covid-19 vocabularies. Creswell argues that qualitative research is a means of exploring and understanding the meaning of individual or group human problem, [23]. The data sources are classified into primary and secondary. The primary resources were taken from BBC and CNN online (March-August 2020) and other multi-media such as, WhatsApp, Line and website. The secondary data uses relevant data which were also taken from some referents related to some concepts on lexicology and semantics that support the study. Those references are the form of Handbook, thesis, articles, e-book, etc. 
a. Data Collection.

To obtain the appropriate data the writers conducted some steps. First, reading newspaper and multimedia several times to understand the whole notions of covid-19 related to this study. Second, identifying the problem as the main issue. The third, is listing the theory and the issue of the notion of covid-19. Fourth, is listing the vocabularies which reflected the form and meaning covid-19 in English, Arabic and Indonesian. The fifth is taking a note on the data found. The last is finding the references relevant to the study and data.

\section{b. Data Analysis}

The method in analyzing the data was descriptive method. This method was applied to contribute this study an accurate and systematic description. The analysis focuses on the form and meaning of the words of covid-19 and the theory to show form and meaning of the vocabularies. This study used the language creativity theory of Carter [24], Semantics theory of Riemer [25], morphology theory of Haspelmath and Sims [26]

\section{RESULT}

Based on it, there are several new words such as: social distancing, or physical distancing. It refers to keeping a safe space between yourself and other people who are not from your household. In practice one has to stay at least about two arms-length from other people who are not from your household in both indoors and outdoors.[27], [28]. Social distancing is one way to reduce mortality and morbidity. The benefits of social distancing are highly dependent on individual understanding. It can be seen from social practices in everyday life in society. Now, the government has replaced the term social distancing to physical distancing. When implementing social distancing, a person is not allowed to shake hands and has to maintain a distance of at least 1 meter when interacting with other people, especially with people who are sick or at high risk of suffering from Covid-19. Social distancing is generally applied, namely: a) work from home; b) Study online at home for school and college students; c) People have suggested by the government that they do not visit people who are sick. They can call them by telephone or video call. Apart from social distancing, there are also other terms related to efforts to prevent Covid-19 infection, namely self-isolation protocols. Self-isolation requires everyone to live in their own home while doing physical control with others. Governments in various countries encourage everyone to carry out independent isolation, especially for certain groups, namely: a) people who have symptoms of Covid-19, such as fever, cough, and shortness of breath and do not have comorbidities, such as diabetes, heart disease, and HIV infection; b) People who are suspected or have been confirmed positive for Covid-19; c) People who have a history of traveling to the red zone or Covid-19 endemic areas within the last two weeks; d) People who have undergone a Covid-19 rapid test. Triana et.al [29], Guo et.al [28] and Yanti et.al [4] use the social distancing concept to propose a prevention framework for self-protection model checking. Thus far, in the public communication through multimedia has impacted to build public awareness. Public have the awareness to receive information from the government regarding ideas, notions, mind-sets, and actions towards social distancing as one of the ways to prevent transmission of the virus. The spread of the virus problems has basically been solved.

The wearing of a mask is important for everyone. The spread of the coronavirus can be transmitted between humans through droplets (saliva particles) when the patient sneezes or coughs. One deficiency of preventing transmission of the virus-based social practice assumption method is wearing mask. Social practice refers to the behavior of wearing a face mask. The most effective prevention of Covid-19 is wearing a face mask to reduce airborne virus transmission [27]. However, the facts show that many people are reluctant to wear face masks in the context of the Covid-19 pandemic [30]. The use of facemasks has been recommended by the Center for Disease Control and Prevention to help reduce the spread Covid-19. Nevertheless, the public is debating about the effectiveness of wearing masks despite the safety testing of mask raw materials. The purpose of wearing a mask is to help reduce transmission. Kevin [31] studies show the benefits of wearing masks to reduce the spread of infection and adverse clinical outcomes, especially when combined with an on-site shelter strategy vulnerable population. Kevin analyzes the importance of using a mask. His study is based on identifying infections with pre-symptomatic and asymptomatic. The use of face masks to maintain public health before a safe and effective vaccine is available. These steps need to be informed to the public by providing information on public health mitigation strategies to control the ongoing outbreak. The recommendation to wear masks has been applied by the government to healthy people, not limited to those who are sick. Another vocabulary that reflects social behavior or social practices are such as work from home, work from office, throat swab test, swab test, social restriction, self-quarantine, self-isolation, rapid test, rapid strep test, protocol, physical distancing, hazmat suit, herd immunity, etc. 
The idea of social distancing and wearing a mask are interpreted as creativity. The concept of creativity has been used by many theorists to illustrate the features of that language permits language users to use language in new ways or to design new forms of it. Carter in particular uses the "creative aspects of language use" to describe innovative use of language. English, Arabic, and Indonesian are like any other language, tools for shaping thoughts and performances attitude; therefore, language users always have the power to adapt the code to their needs, with the result that the rules of language can be observed, bent or violated, and 'marked in violation of the rules and norms of language [24] are precisely conventional .description of linguistic creativity. This study explores the notion of creativity in linguistic theory. An examination is made of its application by Carter [32], from his earliest work on. At least two different notions are distinguishable: rulegoverned creativity and rule-changing creativity. In the current pandemic era, health, social, language institutions, and even a mature speaker can produce new words his language at appropriate occasions, and others the speaker can understand it immediately, though new to them. Most of that linguistic experience, both as speaker and listener, with new sentences; once they have mastered a language, class sentences with which we can operate smoothly and without difficulty or indecision so broad for all practical purposes.

This paper presents some improvements wordformation based on Plag [33], [26] and language creativity based on Carter framework [32]. On one hand, our optimization is to understand vocabulary related to Covid-19 is a form of communication carried out by the public through written language contained in multimedia. Understanding words related to Covid-19 is useful for the public to recognize the meaning of these words. Social practices related to the mitigation of transmission depend on the quantity and quality of vocabulary possessed by each member of the community. A person's Covid-19 words are the whole world in a person's memory that will cause a reaction when they have seen, heard, or read.

The rest of the paper is organized as follows. Section 2 Multimedia as online interaction. It describes that humans need to communicate to understand each other.-Multimedia is an online social interaction forum. Section 3 Word and Meaning. It describes three parts namely synonym, borrowing, acronym, and abbreviation. Finally, Section 4 concludes the paper and presents direction for future research.

\section{DISCUSSION OF RESULT}

Humans need to communicate to understand each other.-Multimedia is an online social interaction forum. The interaction can take the form of one to one or one to many. The impact of the interaction model can affect people's behavior, attitudes, health mitigation, and delivery of information well. Currently, many ideas in the form of new vocabulary, both spoken and written, are spread out through multimedia technology. Unlike chat using the mouth between person to person, multimedia is used in mass communication. The reason is, this method requires a device so that the information is transmitted. On the other hand, the covid-19 plague forces community involvement with digital technology to obtain information related to this disease and the public can carry out certain social practices to avoid the spread of the disease. Multimedia is used as a tool to convey new information among users quickly and widely which was pioneered respectively by Al-Qaysi [34] and Engelbrecht [35] in the middle 2020's. A multimedia is an online tool where many activities is carried out by the public. The information obtained online significantly influences public attention and their health behavior. The public looks for information through the media due to the difficulty in accessing reliable information from reliable sources during the pandemic. Therefore, people are increasingly choosing to search for relevant information via multimedia or the web. The various concepts conveyed in the form of new vocabulary are curious things to find out the meaning, how to act, measure, and understand it that have emerged from the topic of the COVID-19 pandemic. These numerous emerging vocabularies are essential to establish effective and efficient disease control policies. COVID-19 is a new disease that has shown unique characteristics seen from various points of view, which have manifested in the following aspects. First, public mitigation is needed to prevent the large-scale spread of the virus. Second, the lack of foodstuffs and medical protective equipment affects life and disease prevention. Third, the uncertainty of returning to school due to COVID-19 affects economic and social development and learning efficiency. Fourth, multimedia, social media, and other channels on the Internet facilitate the spread of fake news about COVID-19. In other words, the COVID-19 pandemic has deeply affected life, work, study, and social practice, the behavior patterns of each person over a long period, causing different levels of stress reactions that can emerge the idea in the form of vocabulary. Therefore, the current study contrasts English to Arabic and Indonesian to concerning the realization of the three languages, when viewed from a phonological perspective, have similarities and differences, which show that all three reflect the same meaning. This study provides information on Covid-19 words in English, Arabic, and Indonesian. 


\section{Vocabulary}

Vocabulary refers to a collection of words. Every word consists of phonemes. A phoneme is the smallest language unit. From combining several phonemes will form a word that has meaning. Conceptually, vocabulary has three different meanings: a) all of the words in a language; $b$ ) the words used in a particular context; c) the richness of words contained in a language. All the words contained in a language and those words are used in the delivery of knowledge, science, the richness of words that belong to the language community. In the context of English, Arabic, and Indonesian have new words related to the pandemic in terms of their basic form and its formation.

There are many vocabulary forms that is used in form of synonyms, borrowings, abbreviations, acronyms. There are even various words for the same concept. Instead, problems related to the phenomenon of the diversity of terms COVID-19 needs to be given attention to ensure that the terms used can be understood and practiced by users because these terms are related to health and public welfare. To respond the first research question, a descriptive analysis is used to find vocabulary forms related to covid-19 used by English, Arabic, and Indonesian in providing information about the disease. This discussion starts from several aspects, such as competence of a user of language.

\section{Word and Meaning}

During the current outbreak, communication using language is very important. Every society involved in interaction requires factual requirements. These requirements include mastering the vocabulary of the language community. Words are used to express ideas and can make sentences to convey thoughts and feelings to other members of society. The word as a unit of the vocabulary of a language contains two features, namely: a form and a content. A form is something that can be perceived by the five senses. The content is meaning refers to reactions that exist in the human mind due to stimulation from the aspect of the form of language. Meaning has a relationship between the form and the things it references. In short, understanding a word must know the form and reference. Each form of language has a structure of a lexical. It referred to the various semantic relationships contained in it.

\section{Synonym}

A synonym is a study of various words that have the same meaning or conditions in which two words have the same meaning [36].

\section{Figure 1 Synonymous}

These analyses are as follow the synonymous words within the sentence. In this case, only the English synonymous is analysed the interpretation meaning of synonymous word on the sentence is equal with the original meaning. For example:

\begin{tabular}{|c|c|c|c|}
\hline $\mathrm{No}$ & English & Arabic & Indonesian \\
\hline 1 & $\begin{array}{l}\text { coronavirus } \\
\text { test }\end{array}$ & اختِبار فِيِروس كُورُونا & $\begin{array}{ll}\text { uji } & \text { virus } \\
\text { corona } & \\
\end{array}$ \\
\hline \multirow[t]{2}{*}{2} & face shield & وَافِفى الوَجْهُ & $\begin{array}{l}\text { alat } \\
\text { pelindung diri }\end{array}$ \\
\hline & $\begin{array}{l}\text { protective } \\
\text { visor }\end{array}$ & - & - \\
\hline \multirow[t]{2}{*}{3} & $\begin{array}{l}\text { lockdown, } \\
\text { solitary }\end{array}$ & حظظر & $\begin{array}{l}\text { karantina } \\
\text { wilayah }\end{array}$ \\
\hline & isolation & رإِغْلاقُ & - \\
\hline
\end{tabular}

The word "lockdown" in English is synonymous with the word "isolation" and "solitary". Furthermore, to see whether they are synonymous, they need to be substituted in the use of sentences such as the following example: a. I need to know if the infected town is still under lockdown; $\mathrm{b}$. There was a solitary patient in Wisma Atlet; c. Isolating yourself from others might make you feel depressed. In terms of language variety, the three words have differences. In sentences a-c, the words lockdown, isolation, and solitary can be used in formal types and non-formal. However, when it viewed in terms of taste value, the three words are the same worth a neutral taste. Then, seen from the social level of use, these three words also equally applicable in society at any social level. The same thing happened in Arabic,

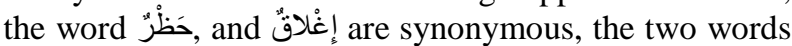
have the same meaning, namely 'lockdown'. Further in Bahasa Indonesia, only has a word for expressing lockdown namely 'karantina wilayah.' Based on the results of the analysis above, it can be concluded that the three words, namely lockdown, isolation, and solitary are synonymous, in English. The word حَظْر and are synonymous in Arabic.

\section{Borrowing}

The spread of Covid-19 has increasingly made it potential for meetings between communities in the world. In this contact, each community carries and introduces diverse cultures and concepts to other societies. Currently, the term Covid-19 is not only produced by utterance but also by written signs. The phenomenon of Covid-19 vocabulary was made to meet the communication needs of the community. One of the efforts to increase the vocabulary of a language is to adopt words from a foreign language is called borrowing. 


\section{Definition 2. The emergence of new words: borrowing}

Borrowing is a process to add new vocabulary item in a language [37]. Carter [32] explains pp. 109 the emergence of the new vocabulary is a manipulation that has social and critical goals. Language creative thinking can be used to 'show identity'. Thus, by using language creatively, speakers may wish to demonstrate their ability to 'offer new perspectives on ideas or things. Carter [32] gives definition (pp. 148) the language creativity in common everyday speech are also highly varied and can, as we have seen, include: offering some new way of seeing the content of the message; making humorous remarks; underlining what is communicated; expressing a particular attitude, including negative and adversarial attitudes; making the speaker's identity more manifest; playing with language form to entertain others; ending one bit of talk and starting another.

\section{Figure 1 Borrowing}

These are seven English, Arabic and Indonesian coronavirus terminologies or words, which are presented in the form of free morpheme in this analysis the writers also want to divide into two kinds of meaning. First is borrowing with no change of meaning and second is borrowing with change of meaning. In this case, the interpretation meaning of borrowing on the sentence is equal with the original meaning. The analyses are as follow: the borrowing with no change of meaning in the sentence. In this case, the interpretation meaning of borrowing on the sentence is equal with the original meaning. The word coronavirus, (BBC online newspaper, November 13, 2020) [38], for example in sentence: a) Coverage of the Scottish government's corona briefing with reaction, expert analysis and the very latest updates from Scotland and beyond on the pandemic; b) Wuhan pernah menjadi simbol pandemi corona tetapi kini kehidupan sebagaian besar di kota berpenduduk 11 juta jiwa di Cina itu. (Kompas.com online newspaper, October 31, 2020) [39]. Then in Arabic the word corona is used such as follow:

$$
\text { لا شك أنّ كثير في الإعلام يخبر في الصبن عدد الناس ماتو أ }
$$

There is a lot of information circulating in China that many victims have died from Corona.

Figure 2. Borrowing with change meaning

\begin{tabular}{|c|c|c|c|}
\hline No & English & Indonesian & Arabic \\
\hline 1 & outbreak & $\begin{array}{l}\text { 'epidemik, } \\
\text { pandemik' }\end{array}$ & 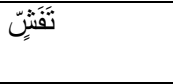 \\
\hline 2 & $\begin{array}{l}\text { community } \\
\text { spread }\end{array}$ & 'penyebaran' & انْنِشتارُ مُجنَمَعِيَّ \\
\hline 3 & social distancing & 'batas untuk & تَبَاعَدُدُ اجتماعيّ \\
\hline
\end{tabular}

\begin{tabular}{|c|c|c|c|}
\hline & & bersosialisasi' & \\
\hline 4 & covid-19 vaccine & 'vaksin' & لِقاحُ كُو فيد \\
\hline 5 & lockdown & $\begin{array}{l}\text { 'penutupan } \\
\text { akses' }\end{array}$ & خَظْرُ \\
\hline 6 & self-quarantine & $\begin{array}{l}\text { 'tinggal di } \\
\text { rumah' }\end{array}$ & حَخْرُ صِِِِيّ ذَاتيّ \\
\hline
\end{tabular}

Datum no.1 in figure 2, the word outbreak refers to 'a sudden rise in the incidence of a disease'. The English, Indonesian, and Arabic sentence are such as:

En We have a fact, Covid-19 outbreak of disease in $\mathrm{g}$ the Indonesia, we are not prepared to cope with it

Ind Ada wabah penyakit Covid-19 di Indonesia, kita tidak siap untuk menghadapinya'

Arb انتشرت وباء الكو فيد 19فى اندونيسيا ولمم تستعد لمواجهتها

The word outbreak from English which is borrowed by Indonesian and Arabic language experienced a change in meaning in the form of upgrading of meaning (amelioration) namely symptoms of a change in meaning from specific to general. Outbreak (noun) means a surge in the spread of a disease. This surge occurred in densely populated areas. If the disease is spread outside the area, but are still close together, it is called an epidemic. The spread of epidemic diseases extends to worldwide coverage, which is called a pandemic. In short, the word outbreak means epidemic, pandemic outbreak. This shows that an outbreak has the meaning of ' epidemic and pandemic. The meaning of an outbreak has expanded its meaning in line with the development of the disease, the condition of society, the cultural context and the development of science in the health sector. The word wabah or plague comes from the Arabic وَبا. The words epidemic, pandemic and outbreak are from the English language. The vocabulary was borrowed into Indonesian.

Another example datum 2, community spread refers to 'the spread of a contagious disease within a community'. The English, Indonesian, and Arabic phrase are such as:

\begin{tabular}{|c|c|}
\hline $\begin{array}{l}\text { English } \\
\text { community } \\
\text { spread }\end{array}$ & $\begin{array}{l}\text { Indonesian } \\
\text { 'penyebaran' }\end{array}$ \\
\hline
\end{tabular}

The phrase community spread meaning 'spread 'goes through upgrading of meaning (amelioration). This is a process of a change in meaning where the meaning will become more upgraded, more general, and is broader in value compared to the previous meaning. The upgrading of the phrase community spread occurs 
when someone is infected by COVID which he or she can't trace who he or she got it from. Gradually, the person will feel the symptoms without knowing where or how the person was infected. Community spread may mean there is a chance the person is infected by covid-19. There is a possibility that the person was infected from other people within his or her community or the person or had travelled to Wuhan. The meaning on the phrase community spread in figure is a change of meaning with the type of upgrading (amelioration), because this phrase experiences a process of changes in meaning where the meaning becomes elevated, and has a broader scope than before. The phrase community spread experiences expansion of meaning into the spread of an illness in certain region where it is not known exactly when and how someone contracted it. Transmission in the concept of community spread is more common and it is difficult to trace the point of origin of the disease than the spread in cluster spread clusters. Based on this fact, it can be concluded that the community spread undergoes an amelioration process. The same analysis was carried out on datum number 3, 4,5 , and 6 in figure 2 that the language unit underwent an amelioration process. Thus, this study found 6 language units in the form of vocabulary that experienced an amelioration.

\section{Meaning analysis}

This word corona is a loan blend type, taken from the word corona in English, which means any of a family (Coronaviridae) of large single-stranded RNA viruses that have a lipid envelope studded with clubshaped spike proteins, infect birds and many mammals, including humans, and include the causative agents of MERS, SARS, and COVID-19. The word corona in English is included in health terminology in Arabic and Indonesian. In this type of loan blend, the combination of two processes, namely foreign language and mother tongue, has some similarities in pronunciation but different spelling. Based on the above meaning in the three sentences, it can be concluded that there is no change meaning. The original word corona in English has the same meaning in Arabic and Indonesian. There are seven borrowing in English, Arabic Indonesia in table 1, such as follow:

Table 1 The borrowing from English to Arabic and Indonesian

\begin{tabular}{|c|c|c|c|c|c|}
\hline No & English & pronunciation & Arabic & pronunciation & Indonesian \\
\hline 1. & $\begin{array}{l}\text { coronaviru } \\
\mathrm{S}\end{array}$ & /kə-'rō-nə-, vī-rəs/ & فيروس كورونا & /fayrus ku:ru:na/ & koronavirus \\
\hline 2. & COVID-19 & /kō-vid-nīn-'tēn/ & كوفيد -19 & /kufid/ & COVID-19 \\
\hline 3. & wuhan & /wuhan/ & وُوهَان & /wuhan/ & Wuhan \\
\hline 4. & virus & /vī-rəs/ & فَفَيْرُوسُ & /fayrūs/ & Virus \\
\hline 5. & plasma & /plaz-mə/ & بِلازْما & /bilāzmā/ & Plasma \\
\hline 6. & remdesivir & /rem-'de-sə-,vir/ & ريمد يسيفير & /ramdasivir/ & remdesivir \\
\hline 7. & $\begin{array}{l}\text { chloroquin } \\
\mathrm{e}\end{array}$ & / klör-ə-, kwēn/ & كلوروكين & /klurukiin/ & klorokin \\
\hline 8 & corona & /ka- 'rō-nal & كورونا & /ku:ru:na/ & Korona \\
\hline
\end{tabular}

The seven word in table 1 shows that these English words were coined by the WHO through a borrowing strategy. The borrowing of the word corona from English into Indonesian, the word corona follows the rules of Indonesian pronouncing / c / in front of the / $\mathrm{a} / \mathrm{,} / \mathrm{u} /$, and $/ \mathrm{o} /$ pronunciation in foreign languages will change to the $/ \mathrm{k} /$ pronunciation in Indonesian so that writing corona is orthographically the truth is korona. The rule of sound change also occurs in words: class $\rightarrow$ kelas; condition $\rightarrow$ kondisi; cultural $\rightarrow$ kultural; career $\rightarrow$ karir. In Arabic the pronunciation / c $/ \rightarrow / \mathrm{k} /$ example in covid $\rightarrow$ kufid, corona $\rightarrow$ kuruna. In brief, Arabic and Indonesian specifically a mix loan from English, the lingua franca, with phonetic modifications.

\section{Acronym}

Currently, the use of acronyms to convey Covid19 information is mostly conveyed from WHO to the public. From a linguistic aspect, the acronym for Covid19 is a symptom of language development.

Definition 3 The emergence of new words: Acronym Plag [33] argues that acronyms are formed words of the initial letter or letter of each successive section. Yule describes [40], [41] that acronyms are new words 
formed from the initial letters of a set of other words. An acronym is a shortening in the form of a combination of letters or syllables or other parts that are written and pronounced as natural words. From the data that have been analysed, the researcher found 192 words. There are five acronyms. The following are the examples of acronym:

Figure 3 Acronym

\begin{tabular}{|c|c|c|c|}
\hline No & $\begin{array}{l}\text { Kind of } \\
\text { acronym }\end{array}$ & Description & Language \\
\hline \multirow[t]{3}{*}{1} & $\begin{array}{l}\text { Capital from } \\
\text { the first of } \\
\text { each word }\end{array}$ & $\begin{array}{l}\text { COVID-19 } \\
\text { (Corona Virus } \\
\text { Disease 2019) }\end{array}$ & English \\
\hline & & فيروس كوفيد-19 & Arabic \\
\hline & & COVID-19 & Indonesian \\
\hline 2 & $\begin{array}{l}\text { Capital from } \\
\text { the first of } \\
\text { each word }\end{array}$ & $\begin{array}{l}\text { SARS-COV2 } \\
\text { (severe acute } \\
\text { respiratory } \\
\text { syndrome- } \\
\text { coronavirus-2) }\end{array}$ & $\begin{array}{l}\text { English, } \\
\text { Arabic, } \\
\text { Indonesian }\end{array}$ \\
\hline 3 & $\begin{array}{l}\text { Capital from } \\
\text { the first of } \\
\text { each word }\end{array}$ & $\begin{array}{l}\mathrm{mAb} \text { or moAb } \\
\text { (monoclonal } \\
\text { antibodies) }\end{array}$ & $\begin{array}{l}\text { English, } \\
\text { Arabic, } \\
\text { Indonesian }\end{array}$ \\
\hline 4 & $\begin{array}{l}\text { Capital from } \\
\text { the first of } \\
\text { each word }\end{array}$ & $\begin{array}{l}\text { Novel } \\
\text { coronavirus } \\
(2019-n \text { cov }) \\
\end{array}$ & $\begin{array}{l}\text { English, } \\
\text { Arabic, } \\
\text { Indonesian }\end{array}$ \\
\hline 5 & & $\begin{array}{l}\text { Epi-curve } \\
\text { (Epidemic } \\
\text { Curve) }\end{array}$ & $\begin{array}{l}\text { English, } \\
\text { Arabic, } \\
\text { Indonesian }\end{array}$ \\
\hline
\end{tabular}

Figure 3 acronym above shows some of the data found by the researcher in order to give some illustration to the readers. While all data totalling, 192 vocabularies related to covid-19 found in this study were available, found acronyms in the form of words that have shortened to capital letters from the front letters, and were easy to read. The data analysis above shows that English has many vocabularies to describe the names of various corona-related diseases compared to Arabic and Indonesian. In short, Arabic and Indonesian use English words to explain the same concept.

The development and use of acronyms related to Covid-19 in English, Arabic, and Indonesian are considered the public as the development of society and culture. However, it has understood as language creativity that occurs due to the pressure of this disease outbreak. The idea of creating acronyms is bound to emerge concerning public mitigation of disease so, its use still refers to the rules of grammar, cultural value as well as the existing socio-health.

\section{Abbreviation}

Nowadays, people are using technology that can make interaction more easily. People communicate in cyberspace using multimedia. These relationships can occur between people all over the world with an internet connection. It makes social contact made it is easy. Indeed, the delivery of Covid-19 information has been disseminated by people through multimedia. The use of the language used also varies. One of the language phenomena that often appears is the abbreviation.

Definition 4. The emergence of new words: Abbreviation

Abbreviation are most commonly form by taking initial letters of multiword sequences to build up a new word [33]. Based on this data, abbreviation is divided into two types: a) initial abbreviation can be fully written in capital letters which is shortened from the first letter of a word; b) initial abbreviation can be written in a capital letter mix with a numeral. The abbreviation in the context of Covid-19 in English Arabic and Indonesian.

Table 2 Abbreviation

\begin{tabular}{|c|c|c|c|c|}
\hline No & $\begin{array}{l}\text { Kind of Initialism } \\
\text { Abbreviation }\end{array}$ & Description & Abbreviation & Language \\
\hline \multirow[t]{6}{*}{1} & $\begin{array}{l}\text { Capitalized } \\
\text { Abbreviation }\end{array}$ & Bacillus Calmette-Guérin vaccine & BCG vaccine & English \\
\hline & & لَلقِّاحُ بِي سنى جي & BCG & Arabic \\
\hline & & Bacillus Calmette-Guérin vaccine & BCG vaksin & Indonesian \\
\hline & & Acute respiratory distress syndrome & ARDS & English \\
\hline & & 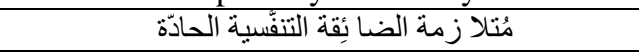 & & Arabic \\
\hline & & Acute respiratory distress syndrome & ARDS & Indonesian \\
\hline \multirow[t]{3}{*}{2} & Mixed Letter & $\begin{array}{c}\text { Severe Acute Respiratory Syndrome } \\
\text { Coronacirus-2 }\end{array}$ & SAR CoV-2 & English \\
\hline & & 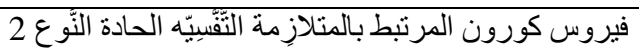 & & Arabic \\
\hline & & $\begin{array}{c}\text { Severe Acute Respiratory Syndrome } \\
\text { Coronacirus-2 }\end{array}$ & SAR CoV-2 & Indonesian \\
\hline
\end{tabular}


Table 2 above showed some data found by the researcher in order to give some illustrations to the readers. It was found that there were two kinds of initials abbreviation; the first, the words that abbreviate to the capital (uppercase) letter, the second is that the abbreviation that is mixed with the uppercase letter (uppercase mixed with lowercase letter), mixed with numeral. It was found that there were two kinds of shortening abbreviations. First, the word that is shortened from the front letter, and the second is the word that is shortened in mix letter. The aforementioned acronyms and abbreviations are often found in written language. The main reason is that acronyms and abbreviations are used to build sentences and make them shorter.

Therefore, acronyms and abbreviations are similar but also have differences. The two types of Arabic abbreviations were coined by the WHO through a loaning strategy, specifically a pure loan from English, the lingua franca, without any phonetic modifications. For better understanding, acronyms, and abbreviations in the classified tables above have the characteristics mentioned. In brief, there are some differences found between acronym and abbreviations. Though they look similar, they are different which can be seen from their characteristics.

\section{CONCLUSION}

Based on language creativity and word formation analysis and focusing on the research question (a) and its analysis, the writers found that language and the users always interact and complement one another in society to provide information. In the context of Covid19 , there are many ways to convey some notions of synonyms, borrowing, acronym, and abbreviation. Generally, ideas related to covid-19 are expressed by WHO in English. That fact can be found easily in daily activities in society, especially in some activities by public networking in multimedia. The lexical structure of synonym, borrowing, abbreviation, and acronym are found in $\mathrm{BBC}, \mathrm{CNN}$ online newspaper, and multimedia in English, Arabic, and Indonesian. In terms of lexical structure, the form of synonyms in Arabic has two or three words to represent an English word, while there is a synonym for a word in English for a word in Indonesian. The language phenomenon in the form of acronyms and abbreviations originates from English, it is also used by the public in Arabic and Indonesian. Arabic borrows 11 Covid-19 words from English meanwhile, Indonesian borrows 68 words.

Henceforth, the writers found several aspects, they are identified as 24 acronyms, 11 abbreviations. This study is expected to give an illustration of the languages in the form of Covid-19 terms or words that are used in the multimedia. In the future, we need to learn more about language used in multimedia or other aspects related to this thesis. In addition, the language used in multimedia will bring about numerous sociolinguistic phenomena, for example, researchers can study the language used related to public health and government information related to the public and social factors of a society.

\section{ACKNOWLEDGMENT}

This work was supported by Translation Department Faculty of Adab and Humanity UIN Syarif Hidayatullah Jakarta, Indonesian Department, FBS Universitas Negeri Manado, Manado, Sulawesi Utara 95618.

\section{REFERENCES}

[1] M. Arnani, 'Timeline Wabah Virus Corona Terdeteksi pada Desember 2019 hingga Jadi Pandemi Global', Kompas, Dec. 03, 2020. https://www.kompas.com/tren/read/2020/03/12/1 13008565/timeline-wabah-virus-coronaterdeteksi-pada-desember-2019-hinggajadi? page $=$ all

[2] Fajrian, '76 Hari Lockdown Wuhan: Warga dan Bisnis Mati karena Corona', CNN Indonesia, Aug. 04,2020 https://www.cnnindonesia.com/internasional/2020 0408124314-113-491628/76-hari-lockdownwuhan-warga-dan-bisnis-mati-karena-corona.

[3] R. A. Harlianty, T. Widyastuti, H. Mukhlis, and S. Susanti, 'Study on Awareness of Covid-19, Anxiety and Compliance on Social Distancing in Indonesia DuringCoronavirus Disease 2019 (COVID-19) Pandemi', Research Square, Jul. 2020, doi: 10.21203/rs.3.rs-44598/v1.

[4] B. Yanti et al., 'Community Knowledge, Attitudes, and Behavior Towards Social Distancing Policy as a Means of Preventing Transmission of Covid-19 in Indonesia', Jurnal Administrasi Kesehatan Indonesia, vol. 8, no. 1, pp. 4-17, Jun. 2020, doi: 10.20473/jaki.v8i2.2020.4-14.

[5] C. R. MacIntyre, 'Global Spread of Covid-19 and Pandemic Potential', Global Biosecurity, vol. 1, no. 3, Feb. 2020, doi: http://doi.org/10.31646/gbio.55.

[6] J. L. Krieger and C. Gallois, 'Translating Science: Using the Science of Language to Explicate the Language of Science', Journal of Language and Social Psychology, vol. 36, no. 1, 2017, doi: https://doi.org/10.1177/0261927X16663256.

[7] T. Rakedzon, E. Segev, N. Chapnik, R. Yosef, and A. Baram-Tsabari, 'Automatic Jargon Identifier For Scientists Engaging with the Public 
and Science Communication Educators', Plos One, vol. 12, no. 1-3, Aug. 2017, doi: https://doi.org/10.1371/journal.pone.0181742.

[8] H. C. Shulman, G. N. Dixon, O. M. Bullock, and D. C. Amill, 'The Effects of Jargon on Processing Fluency, Self-Perceptions, and Scientific Engagement', Journal of Language and Social Psychology, vol. 39, no. 5-6, Jan. 2020, doi: https://doi.org/10.1177/0261927X20902177.

[9] S. Valentin, A. Mercier, Lencelot, and M. Roche, 'Monitorinng online media reports for early detection of unknown diseases: Insight from a retrospective study of Covid-19 emergence.', Blackwell Verlag GmbH, pp. 1-6, Apr. 2020, doi: 10.1111/tbed.13738.

[10] R. De, N. Pandey, and A. Palc, 'Impact of Digital Surge During Covid-19 Pandemic: A Viewpoint on Research and Practice', International Journal of Information Management, Sep. 2020, doi: https://doi.org/10.1016/j.ijinfomgt.2020.102171.

[11] S. Valentin, A. Mercier, R. Lancelot, M. Roche, and E. Arsevska, 'Monitoring Online Media Reports for Early Detection of Unknown Diseases: Insight From a Retrospective Study of Covid-19 Emergence', Transboundary and Emerging Diseases, Feb. 2020, doi: 10.1111/tbed.13738.

[12] E. Arsevska, M. Roche, P. Hendrikx, D. Chavernac, and S. Falala, 'Identifications of Term for Detecting Early Signals of Emerging Infectious Disease Outbreaks on The Web', Computers and Electronics in Agriculture, vol. 123, no. C, pp. 104-115, Apr. 2016, doi: https://doi.org/10.1016/j.compag.2016.02.010.

[13] T.-J. Shih, R. Wijaya, and D. Brossard, 'Media Coverage of Public Health Epidemics: Linking Framing and Issue Attention Cycle Toward an Integrated Theory of Print News Coverage of Epidemics', Mass Communication and Society, vol. 11, no. 2, pp. 141-160, Apr. 2008, doi: https://doi.org/10.1080/15205430701668121.

[14] M. Choi and B. W. McKeever, 'News Framing of Avian Flu: Media Advocacy and Response to a Public Health Crisis', Newspaper Research Journal, vol. 40, no. 4, pp. 451-466, Aug. 2019, doi: https://doi.org/10.1177/0739532919855790.

[15] R. Djalante, J. Lassa, D. Setiamarga, and A. Sudjatma, 'Review and Analysis of Current Responses to Covid-19 in Indonesia: Period of January to March 2020', Progress in Disaster Science, vol. 6, no. 100091, pp. 1-9, Apr. 2020, doi: https://doi.org/10.1016/j.pdisas.2020.100091.

[16] E. Pieri, 'Media Framing and the Threat of Global Pandemics: The Ebola Crisis in UK Media and
Policy Response', Sociological Research Online, vol. 24, no. 1, pp. 73-92, 2019, doi: https://doi.org/10.1177/1360780418811966.

[17] I. G. L. A. K. Wibhisono, 'Framing Analysis of the Kompas Covid-19 Coverage: January 2020 Edition', Jurnal Asosiasi Pendidikan Tinggi Ilmu Komunikasi, vol. 5, no. 2, pp. 219-231, Jul. 2020, doi: http://dx.doi.org/10.24329/aspikom.v5i2.717.

[18] M. A. Camilleri, 'Strategic Dialogic Communication Through Digital Media During Covid-19 Crisis', in Strategic Corporate Communication in the Digital Age, 1st ed., Britania Raya: Emerald.

[19] A. Finset, H. Bosworth, and P. Gulbrandsen, 'Effective Health Communication: a Key Factor in Fighting the Covid-19 Pandemic', Patient Education and Counseling, vol. 103, pp. 873 876, 2020, doi: 10.1016/j.pec.2020.03.027.

[20] S. Łukasz, 'Covid-19 Pandemic; Recession, Virtual Revolution Leading to De-globalization?', Journal of Intercultural Management, vol. 11, no. 1, 2020, doi: 10.2478/joim-2020-0029.

[21] S. M. Utych, 'Messaging Mask Wearing During the Covid-19 Crisis: Ideological Differences', Journal of Experimental Political Science, pp. 111, 2020, doi: 10.1017/XPS.2020.15.

[22] A. Triana, S. Sulastri, and S. Humaedi, 'Ragam Praktik CSR Selama Pandemi Covid-19’, in Penelitian Pengabdian pada Masyarakat, Bandung, Agustus 2020, pp. 435-443, Accessed: Nov. 07, 2020. [Online].

[23] J. W. Creswell, Research Design: Qualitative, Quantitative, and Mixed Methods Approaches, 4th ed. California: SAGE Publications, 2014.

[24] R. Carter, Language and Creativity The Art of Common Talk, Second. New York: Routledge, 2016.

[25] N. Riemer, Introducing Semantics. Cambridge: Cambridge University Press, 2010.

[26] M. Haspelmath and A. D. Sims, Understanding Morphology, 2nd ed. London: Hodder Education, 2012.

[27] J. Humphreys, 'The Importance of Wearing Masks in Curtailing the Covid-19 Pandemic', Journal of Family Medicine and Primary Care, vol. 9, no. 6, pp. 2606-2607, Jun. 2020, doi: 10.4103/jfmpc.jfmpc_578_20.

[28] Y.-R. Guo, Q.-D. Cao, Z.-S. Hong, and Y.-Y. Tan, 'The Origin, Transmission and Clinical Therapies on Coronavirus Disease 2019 (Covid19) Outbreak : an Update on the Status', Military Medical Research, vol. 17, no. 1, Mar. 2020, doi: https://doi.org/10.1186/s40779-020-00240-0. 
[29] A. Triana, S. Sulastri, and S. Humaedi, 'Ragam Praktik CSR Selama Pandemi Covid-19', Bandung, 2020, doi: https://doi.org/10.24198/jppm.v7i2.28869.

[30] M. Howard, 'Gender, Face Mask Perceptions, and Face Mask Wearing: are Men Being Dangerous during the Covid-19 Pandemic?', Personality and Individual Differences, pp. 1-5, 2020, doi: 10.1016/j.paid.2020.110417.

[31] K. Zhang, T. Vilches, M. Tariq, and A. P. Galvani, 'The Impact of Mask-Wearing and Shelter-in-Place on Covid-19 Outbreaks in the United States', International Journal of Infectious Diseases, Feb. 2020, doi: 10.1016/j.ijid.2020.10.002.

[32] R. Carter, Language and Creativity: the Art of Common Talk. New York: Routledge, 2016.

[33] I. Plag, Word Formation in English. Cambridge: Cambridge University Press, 2003.

[34] N. Al-Qaysi, N. M. Nordin, and M. Al-Emran, 'Employing the Technology Acceptance Model in Social Media: a Systematic Review’, Education and Information Technologies, vol. 25, May 2020, doi: 10.1007/s10639-020-10197-1.

[35] J. Engelbrecht, S. Llinares, and M. C. Borba, 'Transformation of the Mathematics Classroom with the Internet', ZDM Mathematics Education, vol. 52, pp. 825-841, Jun. 2020, doi: 10.1007/S11858-020-01176-4.

[36] N. Reamer, Introducing Semantics. Cambridge: Cambridge University Press, 2010.

[37] V. Fromkin, R. Rodman, and N. Hyams, An Introduction to Language, 9th ed. Mexico: Wadsworth, 2013.

[38] D. Wittenberg, 'Covid-19: I've Been Abused because my Name is Corona', BBC News, Sep. 11, 2020. https://www.bbc.com/news/uk-englandmanchester-54868143.

[39] M. K. Wirawan, 'Sempat Jadi Pusat Pandemi Wuhan Kini Incaran Turis', Kompas, Oct. 31, 2020 .

https://www.kompas.com/global/read/2020/10/31/ 125726770/sempat-jadi-pusat-pandemi-wuhankini-incaran-turis?page $=$ all.

[40] G. Yule, the Study of Language. Cambridge: Cambridge University Press, 2013.

[41] L. Bauer, English Word-Formation. Cambridge: Cambridge University Press, 1984. 